\title{
Increased Production and Marketing of Crackers Through Process Improvements in SR Crackers Home Industries in Wonosari Jember
}

\author{
Author \\ Reni Umilasari, Nurhalimah, Miftahur Rahman
}

\section{Correspondence}

Informatics engineering study program Universitas Muhammadiyah Jember, Nursing study program Universitas Muhammadiyah Jember, Informatics engineering study program Universitas Muhammadiyah Jember ilham.saifudin@unmuhjember.ac.id, halimah@unmuhjember.ac.id, miftahurrahman@unmuhjember.ac.id

\begin{abstract}
:
Along with the increase in culinary business units offering various types of food in Jember Regency, the consumption of crackers has also increased. This is because the habits of the Indonesian people, especially in Jember Regency, make crackers as one of the complementary foods on every menu that should not be missed when dining. With the Community Partnership Program activity organized by the PKM Muhammadiyah University Jember team and the SR Crackers Home Industry Partner (IRT) SR has an impact on increasing the income of workers, making crackers faster and varied and reducing unemployment, especially Wonosari villagers can be recruited as workers if increased production capacity. The final target to be achieved is the establishment of a cracker production business unit with appropriate technology, namely with a cracker printing machine, and marketing management with the help of information technology such as market places and social media.
\end{abstract}

Keywords: cracker printing machine, increased production, marketing management, packaging improvement.

Received: 08 Agustus 2019. Accepted: 29 Agustus 2019

\section{Introduction}

Crackers are a crispy snack that is known to everyone and is very popular. Crackers become one of the foods that should not be missed while dining. Crackers have a savory taste with a very crispy texture when bitten. The taste of crackers that appear delicious makes this food so very popular. Ranging from children to adults like crackers. The ingredients for making crackers themselves use flour which is processed by several processes to create crispy crackers. The types of crackers are also very diverse ranging from shrimp crackers, fish, rambak, cassava and others. Demand for crackers on the market is indeed quite high. Where these crackers are loved by many people so that the need for crackers is very large in the community. The high demand for crackers makes this cracker business opportunity very profitable.

Crackers production in Jember Regency is quite high especially in Balung sub-district. However, the number of requests in the field is still much higher. This is evidenced by the frequently encountered in several food stalls many customers are looking for crackers as a side dish almost on every food menu. And there are still many stall owners who do not provide crackers as snacks or complementary food on the grounds that traders who usually sell crackers do not come regularly. This shows the demand / interest in crackers on the market is quite high and will be a promising business opportunity if practiced. With the existence of the cracker printing machine the problem of the length of the production process will be overcome. Manufacturers will more easily and more quickly produce crackers in large quantities with a relatively faster time than using manual equipment.

Crackers production on SR Crackers Home Industry still uses manual cutting techniques ie crackers that have been cooked and dried in the semi-dry will be cut one by one. This is very time and energy consuming considering the amount of production reaches $60 \mathrm{~kg}$ each time with production intensity 2 times a week considering the cutting process also requires a very long time. The number of requests on the market can reach 1000 bags every day. Whereas if production is carried out using a machine, a $60 \mathrm{~kg}$ cracker dough can be completed in just 1 hour, so that production can be maximized given the high number of requests.

Based on an analysis of the situation in the SR cracker production house members, three priority issues can be formulated as follows: 
i. the absence of the application of cracker printing machine technology for making crackers faster and more efficient,

ii. the absence of utilization of marine resources in the manufacture of crackers with various flavors using cracker printing machines,

iii. there is no sales management related to finance and marketing by using information technology to improve competitiveness among cracker producers.

\section{Method}

Based on the solutions and target outputs proposed in the Community Partnership Program (PKM) activities, the stages in implementing solutions in the production activities are described in Table 1, while financial management and marketing activities are shown in Table 2 .

Table 1. Stages of Production Activities

\begin{tabular}{|c|c|c|}
\hline Solution & Outcome & Stage \\
\hline \multirow[t]{2}{*}{$\begin{array}{l}\text { Appropriate Technology } \\
\text { Provision Program }\end{array}$} & \begin{tabular}{|l|} 
Machine Printer \\
Crackers
\end{tabular} & $\begin{array}{l}\text { 1. Identification and collection of follow-up } \\
\text { data to partners. } \\
\text { 2. Making the structural design of cracker } \\
\text { printing machines } \\
\text { 3. Component shopping based on structural } \\
\text { design. } \\
\text { 4. Assemble components based on } \\
\text { structural design. } \\
\text { 5. Testing tools, namely cracker production } \\
\text { with a printing machine } \\
\text { 6. Testing the quality of the results of } \\
\text { making crackers with a printing machine }\end{array}$ \\
\hline & SOP document & $\begin{array}{l}\text { 1. Making SOP for preparing materials and } \\
\text { production equipment. } \\
\text { 2. Making SOP for cracker production } \\
\text { process. }\end{array}$ \\
\hline
\end{tabular}

Tabel 2. financial management and marketing activities

\begin{tabular}{|c|c|c|}
\hline Solution & Outcome & Stage \\
\hline & & $\begin{array}{l}\text { 3. Making SOP for maintenance of } \\
\text { production machinery. }\end{array}$ \\
\hline \multirow[t]{3}{*}{$\begin{array}{l}\text { Crackers Production } \\
\text { Training and Assistance } \\
\text { Program with a variety } \\
\text { of flavors }\end{array}$} & Knowledge and Skills & $\begin{array}{l}\text { 1. Determine the location of training/ } \\
\text { assistance and preparation of materials } \\
\text { and production equipment at partner } \\
\text { locations. } \\
\text { 2. Socialization of utilization and creative } \\
\text { economic business opportunities, namely } \\
\text { making crackers with a variety of flavors } \\
\text { using a printing machine } \\
\text { 3. Training on cracker production practices } \\
\text { based on the five SOPs above with the } \\
\text { aim to be easily understood. } \\
\text { 4. Assistance in order to establish } \\
\text { cooperation and good communication. }\end{array}$ \\
\hline & $\begin{array}{l}\text { Crackers Production } \\
\text { Training and Assistance } \\
\text { Program with a variety } \\
\text { of flavors }\end{array}$ & $\begin{array}{l}\text { 1. Continuous monitoring of participant } \\
\text { skills and implementation of production } \\
\text { activities in the form of regular visits. } \\
\text { 2. Evaluate the level of achievement of } \\
\text { program targets and regular coaching for } \\
\text { the emergence of independent } \\
\text { production. }\end{array}$ \\
\hline & $\begin{array}{l}\text { Intertwined Cooperation } \\
\text { and Communication }\end{array}$ & $\begin{array}{l}\text { 1. Sign a cooperation agreement. } \\
\text { 2. Licensing of products to the Department } \\
\text { of Industry. }\end{array}$ \\
\hline
\end{tabular}

In the Appropriate Technology (TTG) program, the team proposing diversion as (1) providing and selecting the technology to be used in cracker procurement programs in accordance with mutually agreed upon, (2) Testing machines to be used in production activities, (3) document maker. SOP made before. Partners act as providers of information regarding production capacity, production schedules, and the feasibility of production results. Solid collaboration and active participation will produce high-quality, high-value products.

For the training program and assisting in cracker production using a printing machine, the proposing team acts as a trainer and facilitator of production activities, conducts monitoring and initiation of the establishment of cooperation. While partners act as trainees and mentors, the owner and owner of entrepreneurial activities. Motivation in the form of exchanging opinions / discussions, questions and answers, practices, monitoring and evaluation successfully carried out in order to create an independent creative business.

The following will be discussed at the marketing assistance stage through social media and other online media can be seen in the stages below.

1. Making a product catalog that contains various products that are made and will be ordered.

2. Creating social media accounts (Facebook, Twitter, and Instagram) containing various products that are made and which will be ordered in order to find products easily and quickly.

3. Creating an E-Commerce service account (Tokedia and Bukalapak) contains various products that are made and will be ordered to find products easily and quickly.

4. Ensuring the safety of goods ordered online by affixing the delivery receipt number. As for the Tokedia and open shanties already provide security features in shopping online therein.

5. Provide warranty for the products sold.

Net the level of product satisfaction that has been purchased by customers in the form of testimonials / questionnaires.

\section{Results and Discussion}

In this Community Partnership Program (PKM) activities have been carried out which include preparation, preparation of standard operating procedures (SOP) and modules, testing of 
cracker printing machines, as well as training activities and mentoring of cracker production practices with a variety of flavors. The following are some of the activities carried out at the 2019 Community Partnership Program.

\section{a. Preparatory Activities}

The implementation team carries out coordination activities on all parties involved. The parties involved include: chairman (Reni Umilasari), member 1 (Nurhalimah), member 2 (Miftahur Rahman) and target community partners, namely the SR Kerupuk IRT conducted since April 8,2019 . This coordination activity with the aim of compiling a plan community service activities and division of tasks. The Coordination Team with the SR Kerupuk SRT produced an agreement including: the implementation of the activity carried out at the home of the SR Kerupuk IRT owner or cracker production location, the members who would be present at the implementation consisted of 15 people consisting of SR Kerupuk IRT workers, surrounding residents and IRT customers / partners SR Crackers. The implementation will be carried out in July 2019 taking into account engine orders that are scheduled to be completed or ready for use by the end of June. Whereas the exact date will be agreed further. It is also important to discuss the design that will be delivered at the time of the activity, namely in the form of training in printing with packaging machines for packaging crackers and how to market them. The marketing process will be carried out via the internet, including social media and e-commerce services.

The following will describe the results of coordination between the chairperson and implementing members and the target community partners in full as presented in Table 3 .

Table 3. Activity Schedule and Description

\begin{tabular}{|c|l|l|}
\hline No. & \multicolumn{1}{|c|}{ Date } & \multicolumn{1}{|c|}{ Activity Description } \\
\hline 1. & April 2019 & $\begin{array}{l}\text { Coordination between the internal Team, students involved, and partner, } \\
\text { namely SR Crackers Home Industry. As well as ordering the machine at } \\
\text { the Sinar Jaya. }\end{array}$ \\
\hline 2. & May-June 2019 & $\begin{array}{l}\text { Preparation of standard operating procedure documents and cracker } \\
\text { printing training modules with a variety of flavors. }\end{array}$ \\
\hline 3. & June-July 2019 & $\begin{array}{l}\text { Testing the cracker printing machine and preparing / shopping materials } \\
\text { to be used, such as flour, various seasonings, and fish. }\end{array}$ \\
\hline 4. & July 2019 & $\begin{array}{l}\text { PKM Program Socialization for Partner and Training as well as cracker } \\
\text { printing assistance with a variety of flavors. }\end{array}$ \\
\hline 5. & August 2019 & $\begin{array}{l}\text { Promotional socialization of packaging improvement and marketing } \\
\text { strategies for products that have been produced through social media or } \\
\text { other online media. }\end{array}$ \\
\hline 6. & September 2019 & $\begin{array}{l}\text { Monitoring the results of products that have been made as well as } \\
\text { marketing. }\end{array}$ \\
\hline
\end{tabular}

\section{b. Standard Operating Procedure (SOP) Activities}

Before preparing the SOP, the PKM Team first discussed several results of the study related to the recipe of crackers to be used. The results of the discussion are contained in the following table:

Table 4. Basic Recipe for Crackers Dough

\begin{tabular}{|l|l|c|}
\hline No. & \multicolumn{1}{|c|}{ Ingredients } & Frequency \\
\hline 1 & Regular Tapioca Flour & $75 \mathrm{~kg}$ \\
\hline 2 & Premium Tapioca Flour & $25 \mathrm{~kg}$ \\
\hline 3 & Garlic & $1 \mathrm{~kg}$ \\
\hline 4 & Salt & $4 \mathrm{~kg}$ \\
\hline 5 & Flavouring & $0.75 \mathrm{~kg}$ \\
\hline 6 & Sugar & $2 \mathrm{~kg}$ \\
\hline
\end{tabular}

Whereas to vary the taste, the recipe in Table 5.2 can be added to the desired flavor, for example for $100 \mathrm{~kg}$ of basic batter $2 \mathrm{~kg}$ of shrimp is added. Likewise for fish flavor recipes. As for the Standard Operating Procedure (SOP), the process of printing crackers using a machine consists of the preparatory stage and the manufacturing stage as follows:

\section{i. Preparation}

1. Make sure all the tools namely the molding machine, steamer and furnace are ready to use. Additional materials such as firewood and water in the stove must also be prepared. The ability of electricity needed when starting the cracker printing machine has $1300 \mathrm{Watt}$ power. Prepare ingredients in the form of dough crackers that have been mixed beforehand, steaming boards that have been thoroughly laid with a base, and a printing board that will be used by each worker. In detail, preparatory activities include:

2. Check the water tube in the furnace, fill up to $3 / 4$ of the height of the tube / water tank.

3. Light a fire in a furnace that has been given firewood.

4. While waiting for the water to boil, start preparing the cracker mixture according to the agreed recipe.

5. Prepare a bamboo mat for steaming that has been coated with strimin

6. Turn on the engine

\section{ii. Making Stage}

1. The following are the stages of making or printing crackers using a machine.

2. After the five steps in the preparation stage have been carried out, then the next step is to put the mixture into the top tube of the machine 
3. Crackers' dough will come out of 3 machine holes in the form of small pipes on the side of the machine. Begin to print, to rotate the printing board to form crackers like roses. Each printing board consists of 4 crackers.

4. Arrange the cracker mold on a bamboo board that has been coated with strimin to the brim.

5. Perform the printing process to produce \pm 20 stacking boards.

6. Arrange the 20 boards in the steamer that has been prepared

7. Cover the steamer (lower the rope) steaming for about 7 minutes or until the temperature of the steam 'water reaches $2000 \mathrm{C}$.

8. Lift the steaming cover, tie the rope to the prepared pole. For this stage it is recommended to be done by 2 people considering the steaming tool is quite heavy.

9. Let stand briefly to reduce the heat of the bamboo board. To make time efficient while continuing the printing process. After the boards are not too hot, the boards containing the crackers are ready to be dried in the sun.

10. The semi-dry crackers clothesline is immediately separated from the strimin mat/ moved to another clothesline. This makes it easy for removal of crackers so they do not stick on the strimin base.

11. Dry back to dry and ready to be fried

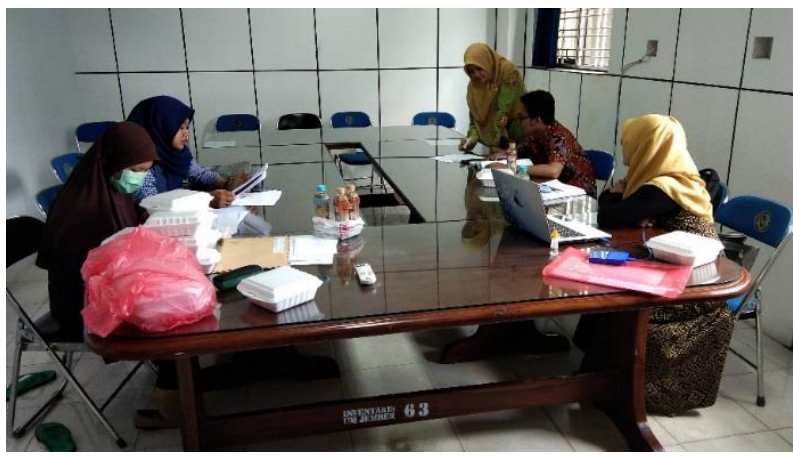

Figure 1. Planning and Finishing Standar operasional prosedur

\section{c. Activities for Ordering and Testing Machine for Crackers}

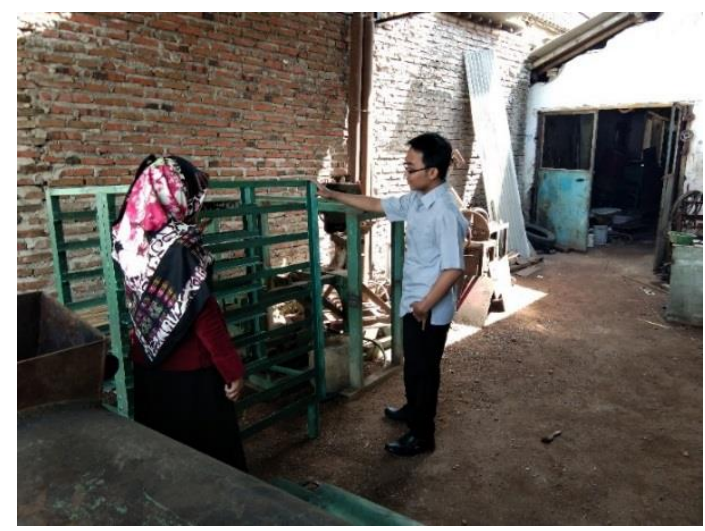

Figure 2. Surveying and Ordering Machine

The beginning of the core activity of the Implementation Team was to conduct a survey and order machinery. This needs to be done considering the machine that will be used with a large capacity at a price that is quite expensive. After going through previous discussions with partners, it was decided that the printing machines to be ordered were not the automatic ones. This is the focus of consideration because if the machine takes out the cracker mold automatically then the involvement of human resources (workers) will be replaced by the machine. So that the machine ordered is semi automatic but the production speed can still be maximized. In addition, the size of the engine and furnace also become the focus of attention. This is because the location or place of production of partners is not too broad. So it was decided to order the furnace with a smaller size, but the quality remained in accordance with needs.

The next activity before the machine is ready for use is of course engine testing. Machine testing is carried out at partner locations with the aim of preparing all equipment properly installed. In this case there are several obstacles when testing, including the engine dynamo damaged, so the Sinar Jaya workshop immediately handle it. Another obstacle is that the power cables at the partner location did not meet the standards, so that during the trial the electric engine had been extinguished several times. This can be overcome immediately so that the machine is re-tested and ready to use.

The following are Figures of machine installation and testing activities accompanied by the Sinar Jaya. 


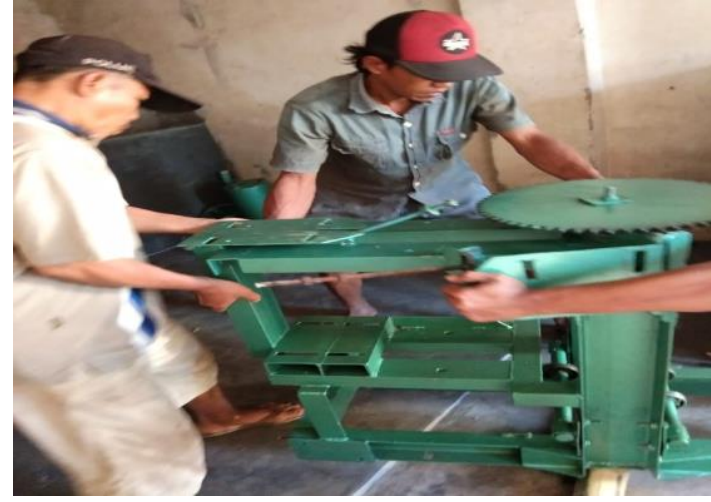

Figure 3. Machine Installation and Testing

\section{d. Dissemination Activities to Partners}

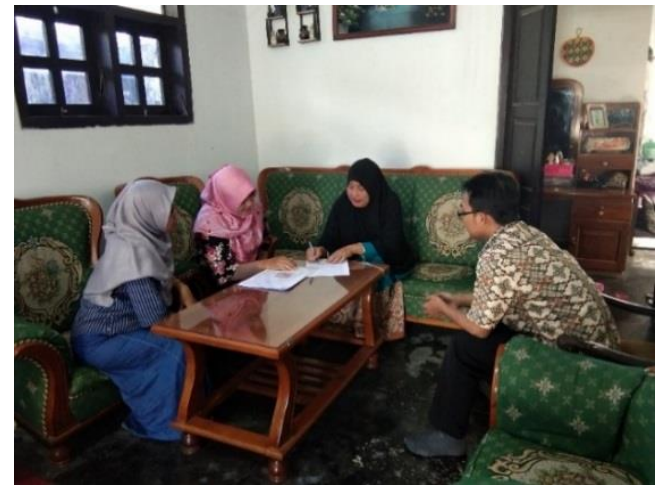

Figure 4. Handover the Machine

Before the training and mentoring activities were carried out, the PKM implementation team conducted socialization and handover of the tools to partners. The device in question is a set of cracker printing machines consisting of molding machines, steamers, and furnaces. The intended socialization activity is a discussion of the training preparation plan that will be carried out on July 5, 2019. The PKM team and partners scheduled a series of activities and made invitations to be given to several prospective trainees.

\section{e. Training and Assistance Activities}

The training and assistance activities began at 08.30 at the residence of Mrs. Sriani as the owner of the SR Kerupuk SR. This activity was divided into three sessions, namely the introduction of theories about the use of tools by the team leader (Reni Umilasari), introduction of cracker dough recipes by member 1 (Nurhalimah), and the last was a practical activity accompanied by the whole team. Participants who attended this activity consisted of 15 people including SR Crackers Home Industry workers, local residents, SR Crupuk IRT partners namely distributors or crackers collectors and food stall owners. The following are Figures from a series of training activities and Community Partnership Program assistance in the SR Crackers.

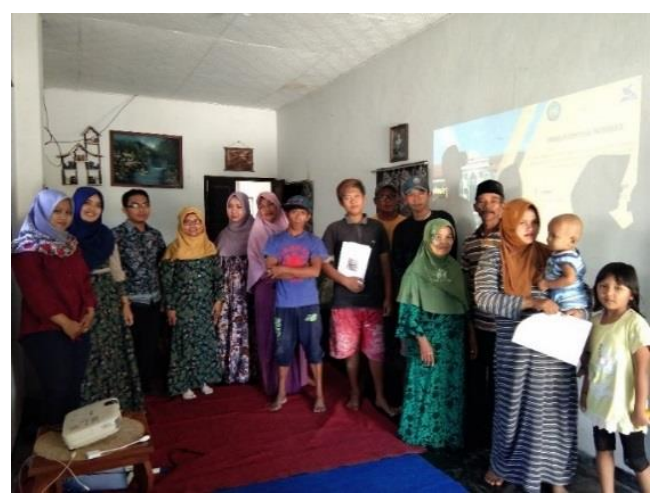

Figure 5. Participants of PKM Training and Assistance at SR Crackers Home Industry

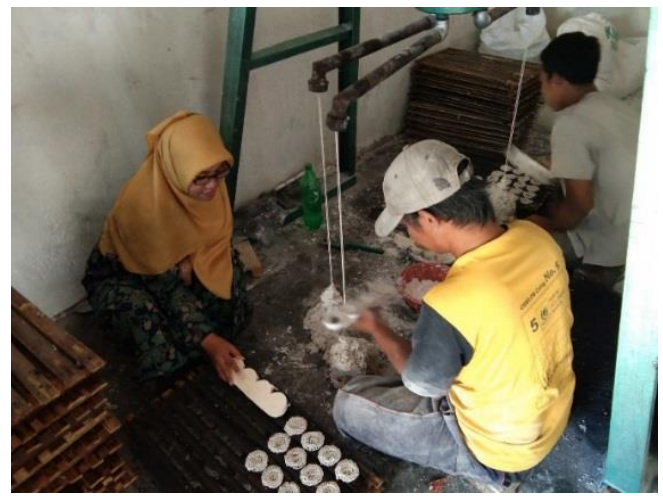

Figure 6. Crack Printing Practice Activities by participants who were accompanied by the PKM

Team

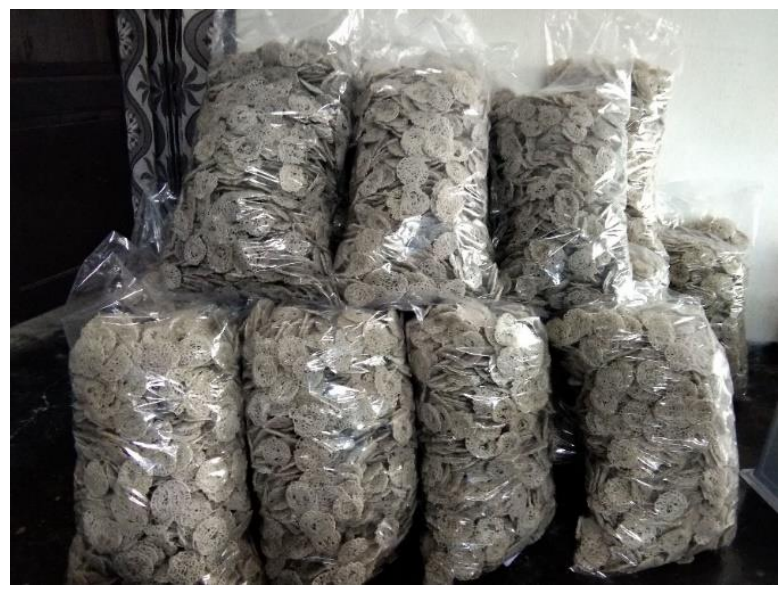

Figure 7. Example of Printing Results of Crackers that are Dry

The last activity in this program is marketing design activities which held on August, exactly on Saturday August 24, 2019. The training place for marketing design in SR Crackers Home 
Industry. The participants who attended the event were 15 members consisting partners of SR Crackers Home Industry, workers, food stall owners. In this activity, an effective marketing strategy training was provided by using ecommerce and social media services. In addition, some knowledge is also provided on how to manage finances properly and correctly. Both by using simple bookkeeping and available applications in computer devices. For example, using an application like Microsoft Excel. This activity is so important to be carried out for the businesssustainability of Crackers. Because basically, the business will run well if marketing and financial management are good too. The implementation of that activities run well like the previously planning.

\section{Conclusion}

1. The Implementation Team consisting of 3 lecturers and 2 students has carried out the design and implementation activities in accordance with their respective assignments.

2. The Implementation Team has made SOP and cracker printing training modules using a machine with a variety of recipes, including onion and fish flavors.

3. The organizer has conducted a socialization to PKM Partners regarding the activities to be held in the form of training and mentoring of cracker production, which was attended by 15 participants consisting of workers, residents, and IRT SR cracker partners properly and smoothly in accordance with the plans that were prepared earlier.

4. Crackers production activities increase with the printing machine, from initially $30 \mathrm{~kg}$ per day to $100 \mathrm{~kg}$ per day. This was followed by an increase in the number of workers, so that PKM activities could reduce unemployment and be able to provide experience and ability in terms of cracker business.

\section{References}

A-29. 1998. Pengolahan Dendeng dan Kerupuk Itik. Palangkaraya: BPTP Palangkaraya Departemen Pertanian.
Ika. 1996. Produk-produk Sampingan Hasil Pengolahan Ikan. Jakarta: Penebar Swadaya

Wahyono, Rudy. 2006. Pembuatan Aneka Kerupuk. Jakarta: Penebar Swadaya

http://kiosmesin.blogspot.com/2014/03/mesinperajang-pengiris-kerupuk-rambak.html . http://www.jember.info/info/kondisiumum/\#ixzz5NiRB1p1D.

http://www.kecsumbersarijember.com/index.p hp/program-kegiatan/program-kegiatankecamatan-dalam-upaya-meningkatkankesejahteraan-masyarakat-tahun-2014/12mata-pencaharian-penduduk 